\title{
Technical Note \\ Small-Scale Spatiotemporal Pattern in the Spawning of Pacific Herring (Clupea pallasii) in the Jinhae Bay, Korea, Estimated Using Hydroacoustic Survey
}

\author{
Hyungbeen Lee ${ }^{1, *}$, Jung Hwa Choi ${ }^{2}$, Seong Yong Moon ${ }^{3}$, Kyounghoon Lee ${ }^{4} \mathbb{D}_{\text {, Wooseok }}$ Oh ${ }^{4}$, Yang Jae Im ${ }^{5}$, \\ Kangseok Hwang ${ }^{1}$ and Doo Nam Kim $^{1}$
}

1 Fisheries Resources Research Center, National Institute of Fisheries Science (NIFS), Tongyeong 53085, Korea; kshwang@korea.kr (K.H.); doonam@korea.kr (D.N.K.)

2 Jeju Fisheries Research Institute, National Institute of Fisheries Science (NIFS), Jeju 63038, Korea; choi2291@korea.kr

3 South Sea Fisheries Research Institute, National Institute of Fisheries Science (NIFS), Yeosu 59780, Korea; msy7744@korea.kr

4 Division of Marine Technology, Chonnam National University, Yeosu 59626, Korea; khlee71@jnu.ac.kr (K.L.); owsnice@gmail.com (W.O.)

5 Distant Water Fisheries Resources Division, National Institute of Fisheries Science (NIFS), Busan 46083, Korea; ocean1982@korea.kr

* Correspondence: hblee00@korea.kr; Tel.: +82-55-650-2250

check for

updates

Citation: Lee, H.; Choi, J.H.; Moon, S.Y.; Lee, K.; Oh, W.; Im, Y.J.; Hwang,

K.; Kim, D.N. Small-Scale

Spatiotemporal Pattern in the Spawning of Pacific Herring (Clupea pallasii) in the Jinhae Bay, Korea, Estimated Using Hydroacoustic Survey. Appl. Sci. 2021, 11, 2058. https://doi.org/10.3390/app11052058

Academic Editor: Pierpaolo Consoli

Received: 20 January 2021

Accepted: 23 February 2021

Published: 25 February 2021

Publisher's Note: MDPI stays neutral with regard to jurisdictional claims in published maps and institutional affiliations.

Copyright: (c) 2021 by the authors. Licensee MDPI, Basel, Switzerland. This article is an open access article distributed under the terms and conditions of the Creative Commons Attribution (CC BY) license (https:// creativecommons.org/licenses/by/ $4.0 /)$.

\begin{abstract}
Acoustic surveys were used to locate coastal Pacific herring (Clupea pallasii) spawning grounds, and the spatial and temporal patterns of their spawning in Jinhae Bay, Korea were examined. We deployed mooring with a newly designed autonomous echosounder for $\sim 70$ days during the Pacific herring spawning season in Jinhae Bay, from January to April 2018. At the same time, shipbased acoustic surveys were conducted to identify the spatial distribution twice, at 38 and $120 \mathrm{kHz}$, onboard the fishing vessel in January and April 2018 in the bay. Fish school signals, including those from adult Pacific herring, are often detected through ship-based acoustic surveys in January, from outside the bay. In the spring, weak scattering signals from fish larvae and zooplankton were continuously detected inside the bay. Backscatter at the mooring in the center of Jinhae Bay was low from mid-January to early March, gradually increasing to higher levels until the end of March. The backscatter observed from the mooring correlated well with ship-based acoustic surveys in the center of the bay. This study proposes that the mooring type acoustic echosounder is a valuable tool for temporal abundance information and other aspects of fish behavior.
\end{abstract}

Keywords: hydroacoustic survey; Jinhae Bay; Clupea pallasii; spawning grounds; spatiotemporal distribution

\section{Introduction}

A species of the herring family (belonging to the order Clupeiformes), Pacific herring (Clupea pallasii) is a cold-water fish that spawns and grows in the coastal waters of Korea, mostly during the winter season, and moves to the high-latitude Bering Sea as the water temperature rises due to seasonal changes [1]. While Korea recorded high catches of the Pacific herring until the 1970s, the amount of fishery resources plummeted due to overfishing and environmental pollution. However, since the early 2000s, catches of the Pacific herring have increased every year due to the improved management of fisheries resources [2,3]. These herring catches are related to climate change. The Pacific herring is in the migration path of the Tsushima Warm Current, which flowed in the East Sea to Uleung Basin in 1987 and 1988, where the water temperature increased from $3{ }^{\circ} \mathrm{C}$ to $4{ }^{\circ} \mathrm{C}$ from 0 to $75 \mathrm{~m}$. However, the water temperature dropped from $5{ }^{\circ} \mathrm{C}$ to $1-2{ }^{\circ} \mathrm{C}$ at a depth of $200 \mathrm{~m}$ in 1992-1993 in the same area [4]. This may have led to an increase in the amount 
of the Pacific herring, a cold-water fish species moving from deep water. The domestic catch of the Pacific herring was recorded as 32,519 tons in 2017, of which 29,438 tons (more than 90\%) was caught in the waters near South Gyeongsang Province. This is highly correlated with the species migration to spawning grounds, which are in Jinhae Bay and Nakdong River Estuary in South Gyeongsang Province where Pacific herring larvae are frequently observed from winter to spring $[5,6]$. Therefore, for the management of the Pacific herring, which migrates to coastal waters, it is very important to protect their spawning grounds. Identifying the number of adult fish in the spawning grounds and the ecological characteristics of spawned eggs and hatched larvae and estimating the initial recruitment accurately will directly contribute to more effective management of fisheries resources, the maintenance of local fisheries, and increased fishery yields.

Jinhae Bay in South Gyeongsang Province is a known spawning ground for the Pacific herring and Pacific cod (Gadus macrocephalus) in Korea. During the month of January, which is the main spawning period, it is prohibited to catch the Pacific cod, a high-value fish species, while no regulations are in place for the Pacific herring. The Pacific herring, being one of the most important links in the marine food chain, is highly correlated with the domestic catches of the Pacific cod, a large cold-water fish species [7]. There have been various studies on the early life stages of the Pacific herring using collection and observation techniques, including the distribution of spawning grounds in Jinhae Bay [8], larval diet [9], and estimation of spawning periods, through scuba observation [10]. However, there has been insufficient research on continuous spatiotemporal distributions using acoustic methods for the spawning habits of adult fish and larval behavior in Jinhae Bay.

The acoustic method yields objective and continuous data for all water layers. Therefore, with the acoustic characteristics of the dominant fish species, it is possible to estimate the spatiotemporal distribution and the existing amounts of major fish species in the survey area. Other countries perform hydroacoustic surveys of various migratory fishes such as the Alaskan cod, Bering Sea pollock, Peruvian anchoveta, and sardine on a regular basis. Korea has published limited research results on the distribution and current amounts of major fish species using acoustic equipment in Asan Bay in South Chungcheong Province (anchovies), Tongyeong in South Gyeongsang Province, Yeosu in South Jeolla Province, and the waters near Jeju and around artificial reefs installed in coastal areas [11-13]. In addition to spatial research using acoustic methods, the movement patterns of fishes and fluctuations in zooplankton have been studied through limited-time or long-term monitoring using moored acoustic equipment such as multi-beam image sonar, acoustic zooplankton fish profiler, and acoustic Doppler current profiler, owing to the advancement of technology [14-16]. In addition, a moored scientific echosounder operated by an internal battery was installed and operated at the bottom of the sea to receive acoustic data on marine organisms on the water layers, so that continuous data, including day/night and seasonal fluctuations in fish and zooplankton and spawning or wintering grounds for fish [17,18], can be obtained in limited areas of water. In ship-based acoustic surveys of fish spawning grounds in particular, the risk of missing the exact spawning time due to changes in the spawning period caused by fluctuations in the marine environment or changes in the survey schedule resulting from sea conditions can be minimized by installing a moored echosounder in the sea [18].

As a result of egg and larval surveys using nets in 2015 and 2016, Jinhae Bay was confirmed as an important spawning ground for the Pacific herring, which plays a pivotal role in the marine food chain [8]. After hatching, young Pacific herring appeared in the eastern waters of Chilcheon Island in the north of Geoje Island, South Gyeongsang Province, the nearby waters of Jam Island, and the southwestern waters of Jinhae Bay, depending on the tidal current of the bay [8]. This study investigated the spatial distribution of the spawning period of the Pacific herring in Jinhae Bay using a ship-based echosounder and identified the exact period during which the adult and immature Pacific herring migrated, by installing a moored echosounder in the nearby waters of Jam Island in the bay and operating it for about 70 days during the fish spawning period from winter to 
spring. The purpose of the surveys was to compare the acoustic results with environmental data to determine the exact timing of the spread after spawning and determine the exact prohibition period to protect Pacific herring resources.

\section{Materials and Methods}

This study investigated the spatial and temporal distribution of adult and immature Pacific herring in Jinhae Bay, South Gyeongsang Province, which is a known spawning and habitat ground of the Pacific herring, by obtaining continuous acoustic data and performing a spatial survey using moored and ship-based echosounders and referring to fishing and environmental data.

To identify the species, fish were caught twice in the waters near Neungpo Harbor, at the entrance of Jinhae Bay $\left(34^{\circ} 53.450^{\prime} \mathrm{N}, 128^{\circ} 44.517^{\prime} \mathrm{E}\right)$ on January 23,2018 , the initial operation of the moored echosounder, and 25 April 2018, after the recovery (Figure 1). A stationary net with a length of $300 \mathrm{~m}$ and a width of $30 \mathrm{~m}$ was used as fishing gear, and the length and weight of every single Pacific herring caught for $24 \mathrm{~h}$ were measured.

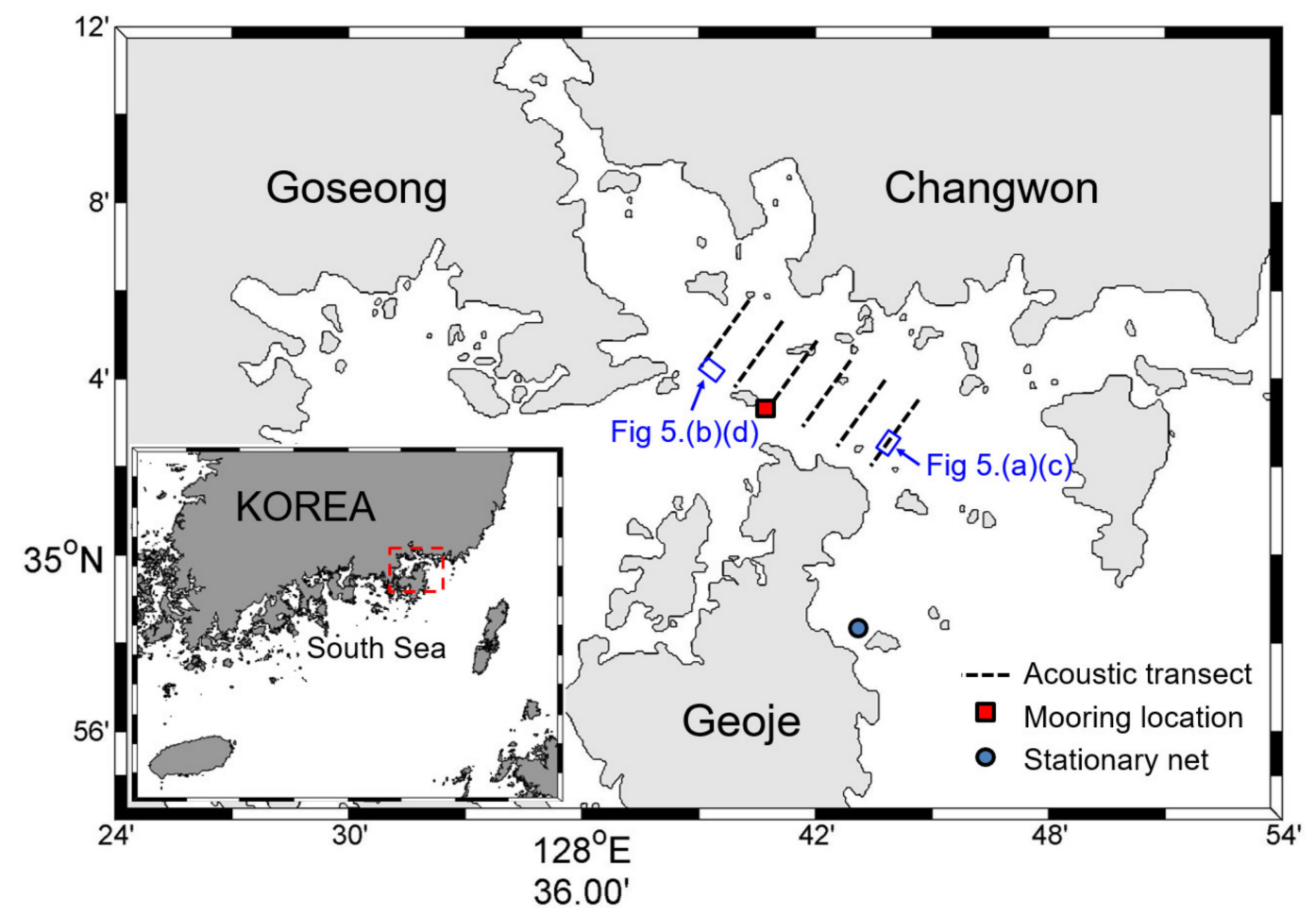

Figure 1. Study area in Jinhae Bay, Korea. The acoustic survey transects are shown as black dotted lines, and the locations of the echosounder mooring are indicated by red squares. The circle represents a stationary net station for fish catches.

For the operation of the moored echosounder, an underwater mount $(100 \mathrm{~cm}$ width $\times$ $100 \mathrm{~cm}$ length $\times 65 \mathrm{~cm}$ height) was made and installed in the waters near Jam Island in the bay $\left(35^{\circ} 3.543^{\prime} \mathrm{N}, 128^{\circ} 40.613^{\prime} \mathrm{E}\right)$, which is part of the migratory path of the adult Pacific herring, in its movement to the spawning and habitat grounds of the larvae (Figure 1). This underwater mount was installed and fixed at a depth of $22 \mathrm{~m}$ by scuba diving, and the mooring split-beam wideband autonomous transceivers (WBATs) (SIMRAD AS) installed on the mount were operated by an internal battery (128 Ah) with split-beam transducers of $70 \mathrm{kHz}$ (model ES70-7CD) and $120 \mathrm{kHz}$ (model ES120-7CD) (Figure 2). With the sensors facing the surface layer, acoustic data were obtained from all water columns, from near the sea floor to the surface. The moored echosounder was operated for about 70 days from 21 January (winter) to 31 March (spring) 2018, when the Pacific herring returned for spawning. During the deployment, the WBATs were programmed to transmit an ensemble 
of 100 pings at the beginning of each hour at a ping interval of $3 \mathrm{~s}$. The pulse width of the transmitted signals was set to $1.024 \mathrm{~ms}$ for both frequencies, and the Tx power was operated at $375 \mathrm{~W}$ and $200 \mathrm{~W}$ for $70 \mathrm{kHz}$ and $120 \mathrm{kHz}$, respectively, depending on the water depth. A water temperature and depth logger (RBR T.D duet, RBR Ltd.) was installed on the underwater mount to supplement the acoustic data analysis. The water temperature data were collected at intervals of $2 \mathrm{~min}$ for the same period as the echosounder.

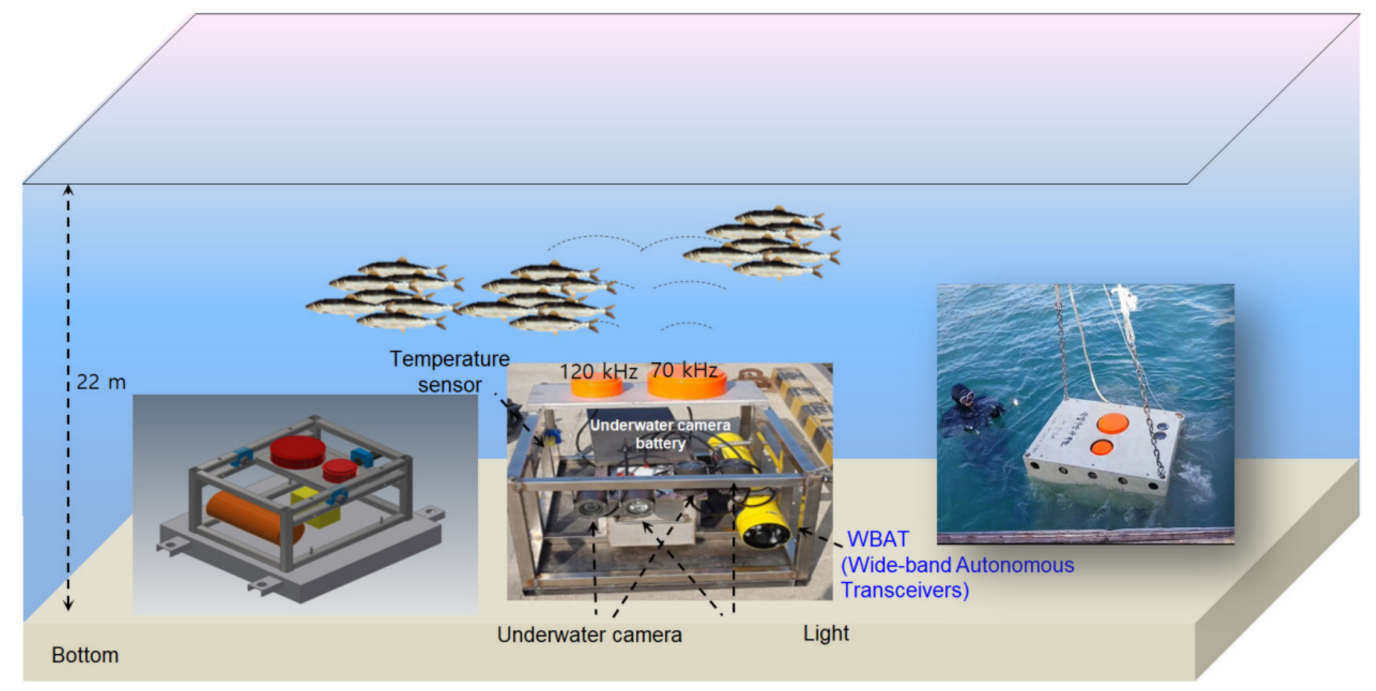

Figure 2. Design of the acoustic monitoring system in Jinhae Bay, Korea.

The spatial acoustic survey in Jinhae Bay using the ship-based scientific echosounder of $38 \mathrm{kHz}$ (model ES38-10) and $120 \mathrm{kHz}$ (model ES120-7C) with a split-beam transducer type echosounder (EK60, SIMRAD AS) was conducted twice, in winter (20 January 2018) and in spring (3 April 2018) (Figure 1). The acoustic survey was performed in six transects, where Pacific herring were expected to pass through in Jinhae Bay. The ship-based echosounder was calibrated before the experiment, and the pulse width and ping interval of the transmitted signals during the operation were set to $0.512 \mathrm{~ms}$ and $1 \mathrm{~s}$, respectively. The acoustic sensor was fixed vertically at a depth of $2 \mathrm{~m}$ on the side of the survey vessel, and the vessel speed was maintained within 6 knots for obtaining accurate acoustic data and sensor stability.

The acoustic data acquired from the mooring- and ship-based echosounders were analyzed for volume backscattering strength $\left(\mathrm{SV}, \mathrm{dB}\right.$ re $\left.1 \mathrm{~m}^{-1}\right)$ using the virtual echogram technique of an echosounder data processor (Echoview Ver. 8.0; Echoview Pty. Ltd.) [19]. Although the SV data from the mooring-type echosounder were obtained for both $70 \mathrm{kHz}$ and $120 \mathrm{kHz}$, this study analyzed only the $70 \mathrm{kHz}$ data. The analysis was performed with MATLAB $^{\circledR}$, by compressing the data at 10-ping intervals after removing sea-level signals made by the sea conditions and noise generated by sensors and near-field communication during transmission, and then extracting SV and nautical area scattering coefficient (NASC, $\mathrm{m}^{2} \mathrm{nmi}^{-2}$ ), which was converted from SV in linear form for comparison of the relative fish density [20]. The NASC extracted during the analysis was calculated as the average value for $1 \mathrm{~h}$ and 1 day.

The data from the ship-based echosounder were analyzed for both $38 \mathrm{kHz}$ and $120 \mathrm{kHz}$. Noise was removed from the SV data obtained while the ship was in motion, and the difference in mean volume backscattering strength ( $\triangle \mathrm{MVBS}$ ) was used to separate adult fish $\left(2 \mathrm{~dB}<\Delta \mathrm{MVBS}_{38-120}<20 \mathrm{~dB}\right)$ from fish larvae and zooplankton $\left(2 \mathrm{~dB}<\Delta \mathrm{MVBS}_{120-38}<20 \mathrm{~dB}\right)[12,21]$. In addition, the data were extracted by converting into average NASC, in the same way as the results from the moored echosounder for each frequency. An elementary distance sampling unit (EDSU) of 0.1 nautical mile was set for the extraction, by considering the stopping distance. 
Before the acoustic survey, a scuba survey was conducted to photograph and identify fish larvae on the Nanpo-ri Coast $\left(35^{\circ} 4.979^{\prime} \mathrm{N}, 128^{\circ} 37.704^{\prime} \mathrm{E}\right.$, depth $\left.5-8 \mathrm{~m}\right)$ in Jinhae Bay in February 2016.

Data from an ocean observation buoy $\left(35^{\circ} 2.633^{\prime} \mathrm{N}, 128^{\circ} 45.700^{\prime} \mathrm{E}\right)$ in Jinhae Bay, which were provided by the Korea Ocean Observing and Forecasting System of the Korea Hydrographic and Oceanographic Agency, were used to examine the fluctuation of water temperature, which is one of the major environmental factors for the spawning of the Pacific herring in the survey area.

\section{Results}

As a result of the survey of stationary net fishing performed twice in order to compare the data obtained from the echosounders in Jinhae Bay, 291 Pacific herring with a total weight of $42.18 \mathrm{~kg}$ were caught. During the first survey performed on 20 January 2018, 258 individuals were collected. The average fork length of the Pacific herring was $26.6 \pm 2.4 \mathrm{~cm}$, and only adult Pacific herring longer than $22 \mathrm{~cm}$ were collected (Figure 3). Meanwhile, on 25 April 2018, which was after the spawning period of the Pacific herring, a total of 33 individuals (mean \pm standard deviation: $22.4 \pm 6.1 \mathrm{~cm}$ ) were collected, which consisted of adult fish ( 26 individuals, $25.4 \pm 1.2 \mathrm{~cm}$ ) and immature fish shorter than $20 \mathrm{~cm}$ (7 individuals, length distribution: 7.9-16.2 cm, mean \pm standard deviation: $11.2 \pm 2.8 \mathrm{~cm}$ ).

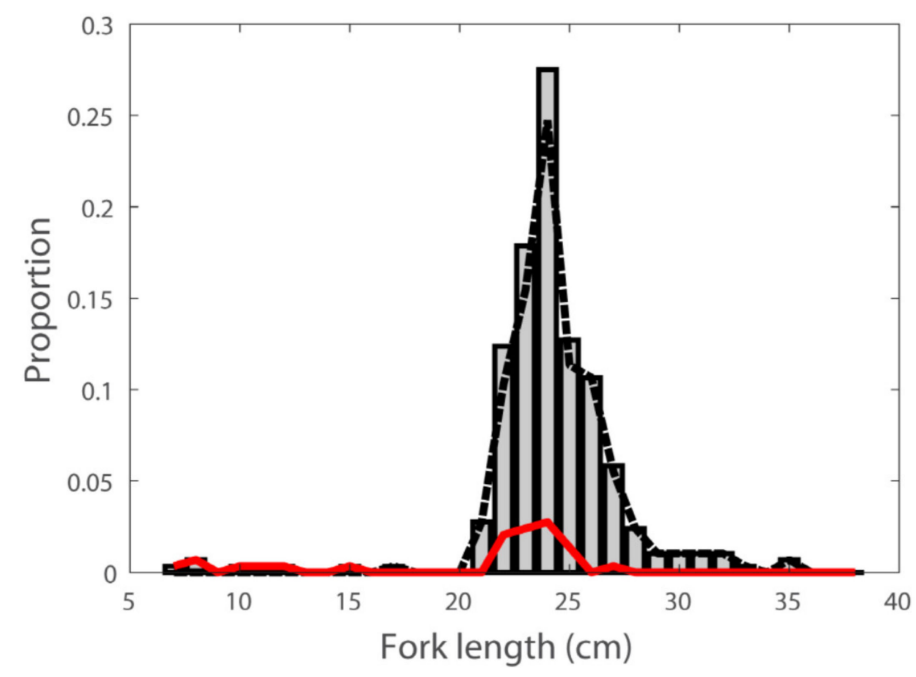

Figure 3. Pacific herring (Clupea pallasii) length-frequency distributions in Jinhae Bay. Gray bars represent the length-frequency distribution in the two combined surveys. The black dashed and red solid lines indicate the length-frequency distribution during January and April 2018, respectively.

The bottom water temperature logged by the moored echosounder at a depth of $22 \mathrm{~m}$ was measured in the range of $5.11-11.68{ }^{\circ} \mathrm{C}$ (average, $7.47^{\circ} \mathrm{C}$ ) during the mooring period from 21 January to 31 March 2018 (Figure 4a). When the mooring was installed, the bottom water temperature was $7.9^{\circ} \mathrm{C}$ on 21 January 2018 , which decreased to below $5.5^{\circ} \mathrm{C}$ by 15 February 2018. Since then, the water temperature had risen to $11^{\circ} \mathrm{C}$ or higher by the end of March 2018. 

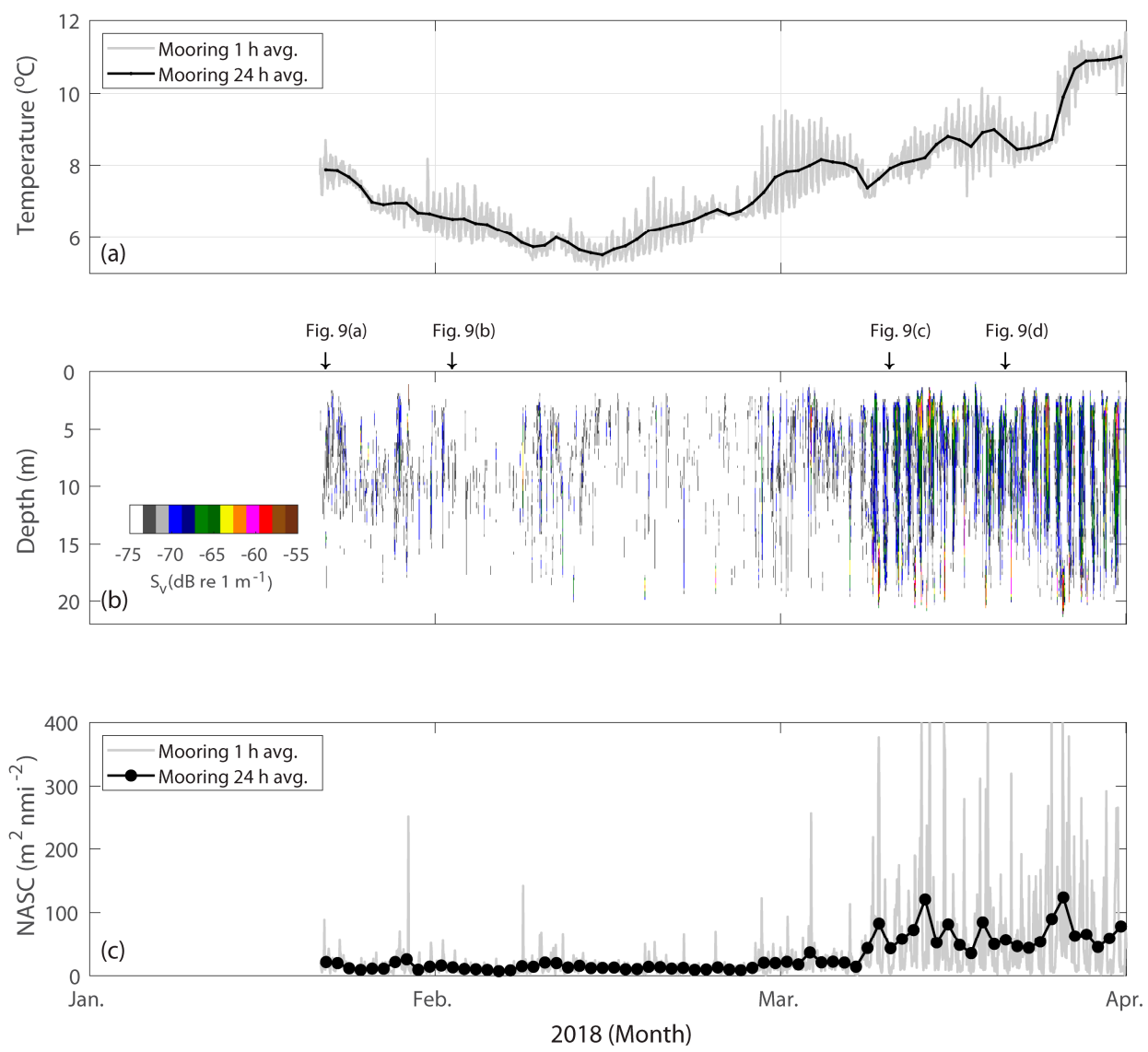

Figure 4. Temporal variability in water temperature and acoustic backscatter at a mooring site: (a) bottom water temperature, (b) volume backscattering strength (SV) ( $\mathrm{dB}$ re $1 \mathrm{~m}^{-1}$ ), and (c) nautical area scattering coefficient (NASC) $\left(\mathrm{m}^{2} \mathrm{nmi}^{-2}\right)$. The light gray lines indicate the average of the 100-ping ensembles collected hourly; the black lines and circles show the daily averages in (a,c).

High levels (>-60 dB) of SV mainly occurred from $5 \mathrm{~m}$ to $20 \mathrm{~m}$ between 7 March and 31 March. During winter (January to February), relatively low acoustic backscattering $(-75$ to $-70 \mathrm{~dB})$ was observed over the water column (Figure $4 \mathrm{~b})$. The fish signals were detected intermittently from $3 \mathrm{~m}$ to $15 \mathrm{~m}$ from January to February. From 7 March to 31 March 2018, however, the acoustic backscatter echo levels of small fish were measured at all water levels, and day and night movement patterns were also found.

The data obtained from the moored echosounder showed that the average NASC to compare the relative fish density from the beginning of mooring was $14.60 \pm 5.66$, which is a low level of acoustic backscatter (Figure 4c). After the fish school signals were detected from 7 March to 31 March 2018, the average NASC was $64.81 \pm 23.76$, which is 4.44 times the average NASC (14.60 \pm 5.66$)$ of the preceding 47 days (21 January to 6 March 2018).

Figure 5 shows an example of acoustic data acquired from a ship-based echosounder by frequency. The survey of the transects obtained using the ship-based echosounder in January 2018, which is the winter season, detected many fish school echoes of -51 to $-33 \mathrm{~dB}$ in the transects outside Jinhae Bay, at a low frequency of $38 \mathrm{kHz}$ (Figure 5a). On the other hand, at a high frequency of $120 \mathrm{kHz}$, only weak signals of $-60 \mathrm{~dB}$ or less were detected at the inner bay (Figure 5b). In spring, even at the outer bay, few acoustic signals from fish schools were detected at $38 \mathrm{kHz}$ (Figure $5 \mathrm{c}$ ), while acoustic signals of fish larvae and zooplankton in the range of -65 to $-55 \mathrm{~dB}$ were received at $120 \mathrm{kHz}$ at the inner bay, unlike the survey in winter (Figure $5 \mathrm{~d}$ ). 

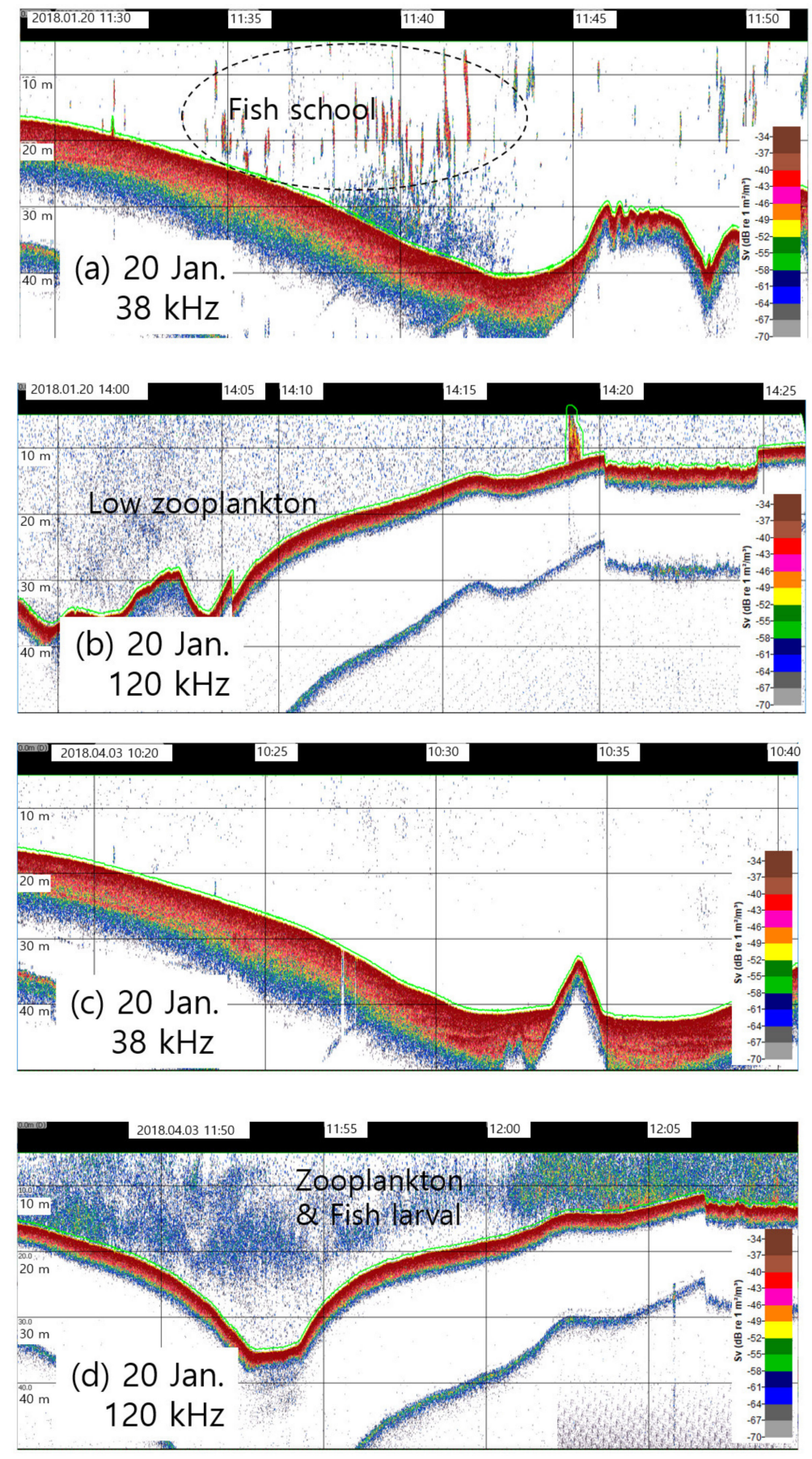

Figure 5. Examples of vertical echograms from the ship-type echosounder measured at $38 \mathrm{kHz}$ (a) and $120 \mathrm{kHz}$ (b) on 20 January 2018, and at $38 \mathrm{kHz}$ (c) and $120 \mathrm{kHz}$ (d) on 3 April 2018, in Jinhae Bay. In January, the $38 \mathrm{kHz}$ echogram showed fish schools on the outside bay (a), and the $120 \mathrm{kHz}$ echogram showed weak scatter in the inner bay (b). In April, the $38 \mathrm{kHz}$ echogram showed no fish echoes in the outer bay (c), and the $120 \mathrm{kHz}$ echogram showed dense scattering, indicating zooplankton and fish larvae in the inner bay.

After the acoustic data obtained from the survey areas were separated into echoes of adult fish and larvae and zooplankton using the difference in mean volume backscattering strength, the extracted $38 \mathrm{kHz}$ fish echoes and $120 \mathrm{kHz}$ zooplankton echoes, including larvae, were converted into NASC and displayed on the transects (Figure 6). In January, few fish echoes were detected inside Jinhae Bay, while a relatively higher level of acoustic backscatter intensity was measured outside the bay (Figure 6a). On the one hand, larval and 
zooplankton signals were low across the bay (Figure 6b). In April, strong signals from adult fish were intermittently detected only outside the bay, and the frequency was relatively low compared to that obtained in winter (Figure 6c). On the other hand, larval and zooplankton signals were detected across the survey areas, unlike in winter, particularly strongly inside the bay (Figure $6 \mathrm{~d}$ ).


Figure 6. Cont. 

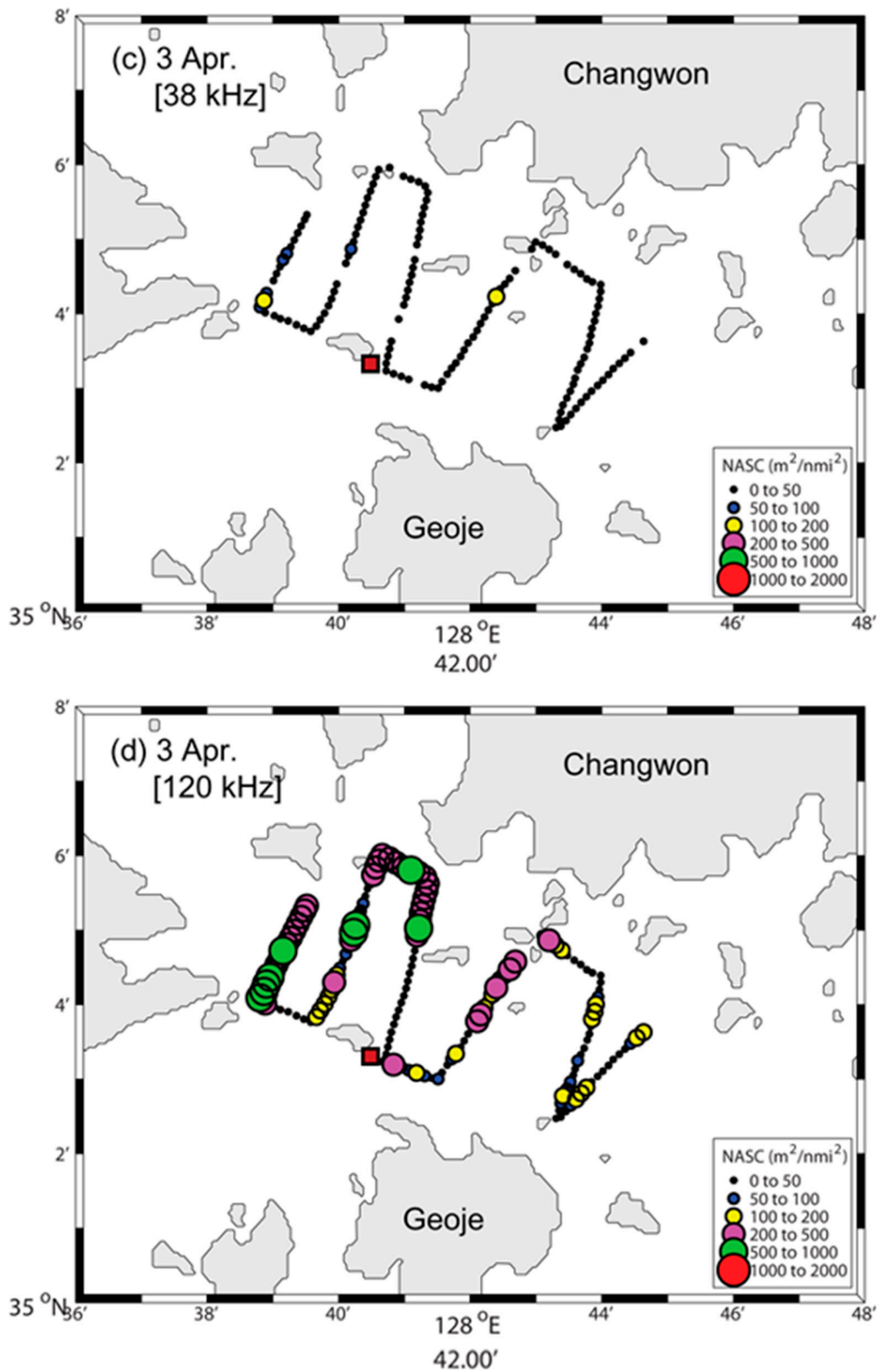

Figure 6. Acoustic backscatter observed in Jinhae Bay. The circles correspond to the observed fish aggregation backscatter using the nautical area scattering coefficient (NASC, $\mathrm{m}^{2} \mathrm{nmi}^{-2}$ ) data with a 0.1 nautical mile interval at $38 \mathrm{kHz}$ (a) and $120 \mathrm{kHz}(\mathbf{b})$ on 20 January 2018, and at $38 \mathrm{kHz}$ (c) and $120 \mathrm{kHz}$ (d) on 3 April 2018. The location of the echosounder mooring is indicated by a red square. A scale bar is provided at the bottom of the figure. The survey data and frequencies are listed on each panel. NASC: nautical area scattering coefficient. 
In February 2016, a group of Pacific herring larvae was photographed in Jinhae Bay (Figure 7). The adult Pacific herring usually spawns sinking eggs in areas where seaweed is distributed at a water depth of $5 \mathrm{~m}$ or less; adult Pacific herring schools move to shallow coasts or inner bays with seaweed communities and lay eggs on surfaces such as seaweed. This indirectly indicates that the Pacific herring spawns before February, and the larvae grow and move to the open sea.

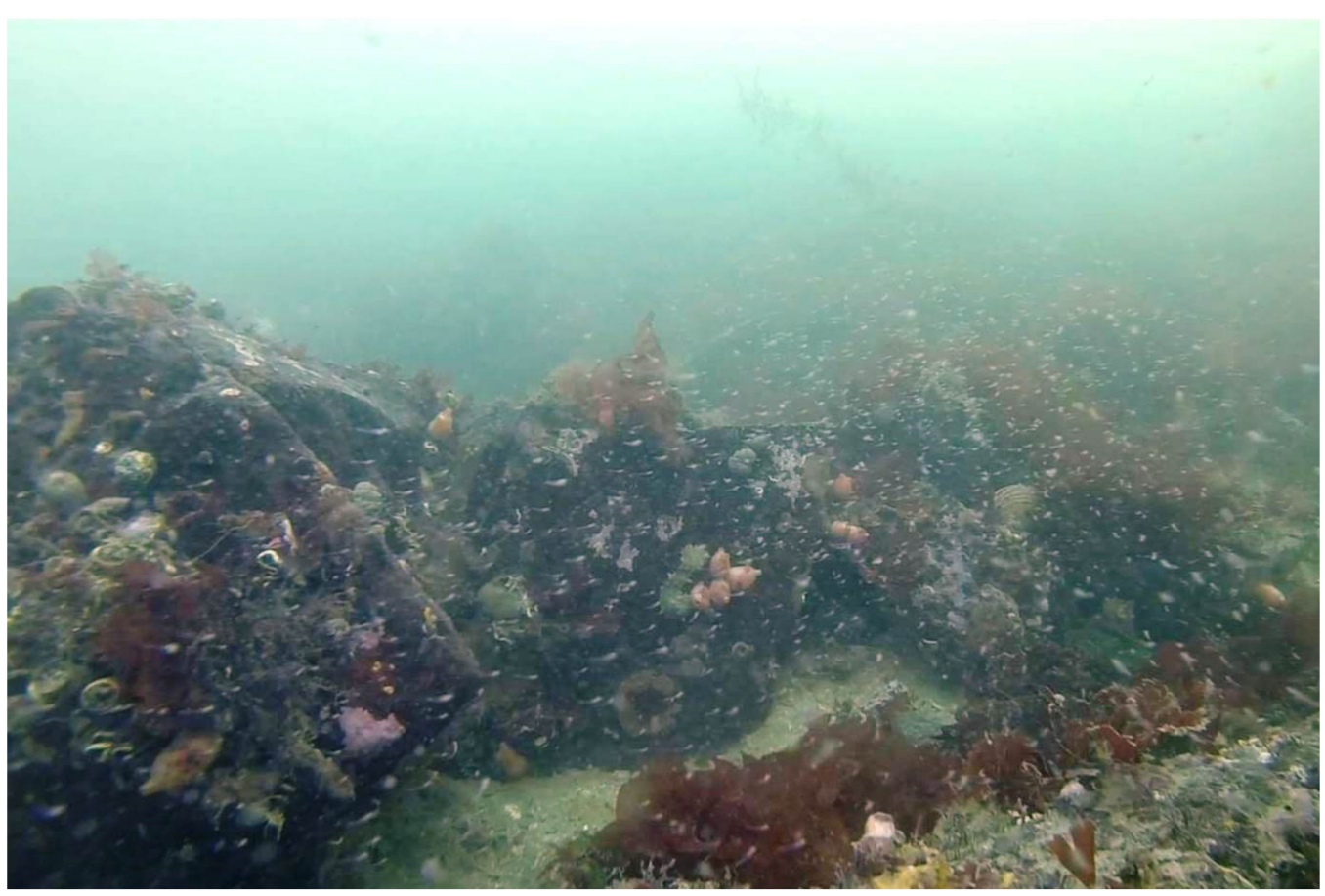

Figure 7. Photograph of the spawning ground of the Pacific herring (Clupea pallasii) during a scuba survey on the Nanpo-ri Coast in Jinhae Bay in February 2016.

The ocean observation buoy in Jinhae Bay has provided data on monthly average water temperatures since September 2015 (Figure 8). The surface water temperature in the winter of December 2017, which is the major spawning period of the Pacific herring, was $11.87^{\circ} \mathrm{C}$, which was about $2^{\circ} \mathrm{C}$ lower than $13.99^{\circ} \mathrm{C}$ observed in 2015 and $13.84{ }^{\circ} \mathrm{C}$ observed in 2016. Although data for January and February 2018 were not available, the surface water temperature monthly averages for March, April, and May 2018 were $10.2^{\circ} \mathrm{C}$, $13.14{ }^{\circ} \mathrm{C}$, and $16.02{ }^{\circ} \mathrm{C}$, respectively. 




Figure 8. Monthly annual variations of the averaged surface water temperature retrieved by the Korea Ocean Observing and Forecasting System of the Korea Hydrographic and Oceanographic Agency in Jinhae Bay from 2015 to 2018.

\section{Discussion}

The location where the underwater moored echosounder was installed is one of the sea areas where the eggs and larvae of the Pacific herring were collected at high densities in Jinhae Bay in 2015 and 2016 [22]. Analysis of the data from the moored echosounder revealed that the acoustic backscatter intensity after mid-March increased compared to the period from the end of January to the beginning of March, which was the initial mooring period (Figure 6b). Although it is difficult to make an absolute comparison of the acoustic data acquired from the moored and ship-based echosounders owing to the difference in frequencies, the results are similar to those of the spatial distribution survey conducted twice with the ship-based echosounder (Figure 5). The ship-based survey found strong signals, considered to be from fish alone, outside the bay in January, and signals matching the levels originating from small fish and zooplankton were detected inside the bay in April. The spatial distribution of the acoustic signals in the bay indirectly shows the general patterns and ecological characteristics of habitat changes according to the growth stage, where the adult Pacific herring migrates offshore for prey after spawning and hatched Pacific herring larvae grow and migrate from the coast to the open sea. As a result of sampling in April, the second fishing season, the catch was reduced to less than $15 \%$ of that in January, but both adult and immature fish were caught, unlike the case in January, when only adult fish were collected (Figure 3). The acoustic data and collection results indicate that the fish were likely to have already migrated further away from the mooring location after spawning, although the mooring was located in the middle of Jinhae Bay (Figure 1). Therefore, follow-up studies are required wherein the mooring location is moved or the mooring is performed in early winter.

Pacific herring have a swimbladder [23], and echo data from fish with swimbladders may be distinguished from echo data from zooplankton or fish without swimbladders [24]. The length distribution of Pacific herring larvae collected from Jinhae Bay during winter was found to be 5 27 mm using an RN80 net in 2011 [9]. The acoustic target strength (TS; $\mathrm{dB}$ re $1 \mathrm{~m}^{-1}$ ) of Pacific herring at $70 \mathrm{kHz}$ is between -72.8 and $-58.2 \mathrm{~dB}$ from 5 to $27 \mathrm{~mm}$, respectively [23]. On the other hand, the zooplankton community in Jinhae Bay is mainly composed of large copepods, Acartia omorii and Centropages abdominalis, in winter and spring [25]. The adult prosome length of $A$. omorii and C. abdominalis was less than $2 \mathrm{~mm}$ in Jinhae Bay [25]. The contribution of these copepods to SV was negligible because of the low mean TS, which was reported to be below $-100 \mathrm{~dB}$ for 2.57-mm-long copepods at $70 \mathrm{kHz}$ [26]. 
Aggregation patterns typical of pre-spawning fish schools were evident in the mooring records, and there was evidence of rapid changes in local abundance (Figure 9). The observations at the mooring indicated that fish distributions were changing during the spawning season. Backscattering at the mooring was low on 21 January and 1 February (winter), increasing to high levels on 11 March and 21 March (spring). In a previous study in 2009 , more than $80 \%$ of larvae were identified as herring from January to March as a result of monthly larval surveys in southwest Jinhae Bay [5]. The mooring area for the migration of the Pacific herring should be moved from the bay to the Pacific Ocean [1]. The acoustic level range of the detected echoes in the mooring is characteristic of fish, and typical acoustic echoes characteristic of zooplankton form scattering layers. In the case of fish, on the other hand, echoes up and down on the echogram suggest a sparse fish school. Therefore, it is highly likely that the echoes detected in the mooring system will be mainly from Pacific herring larvae.
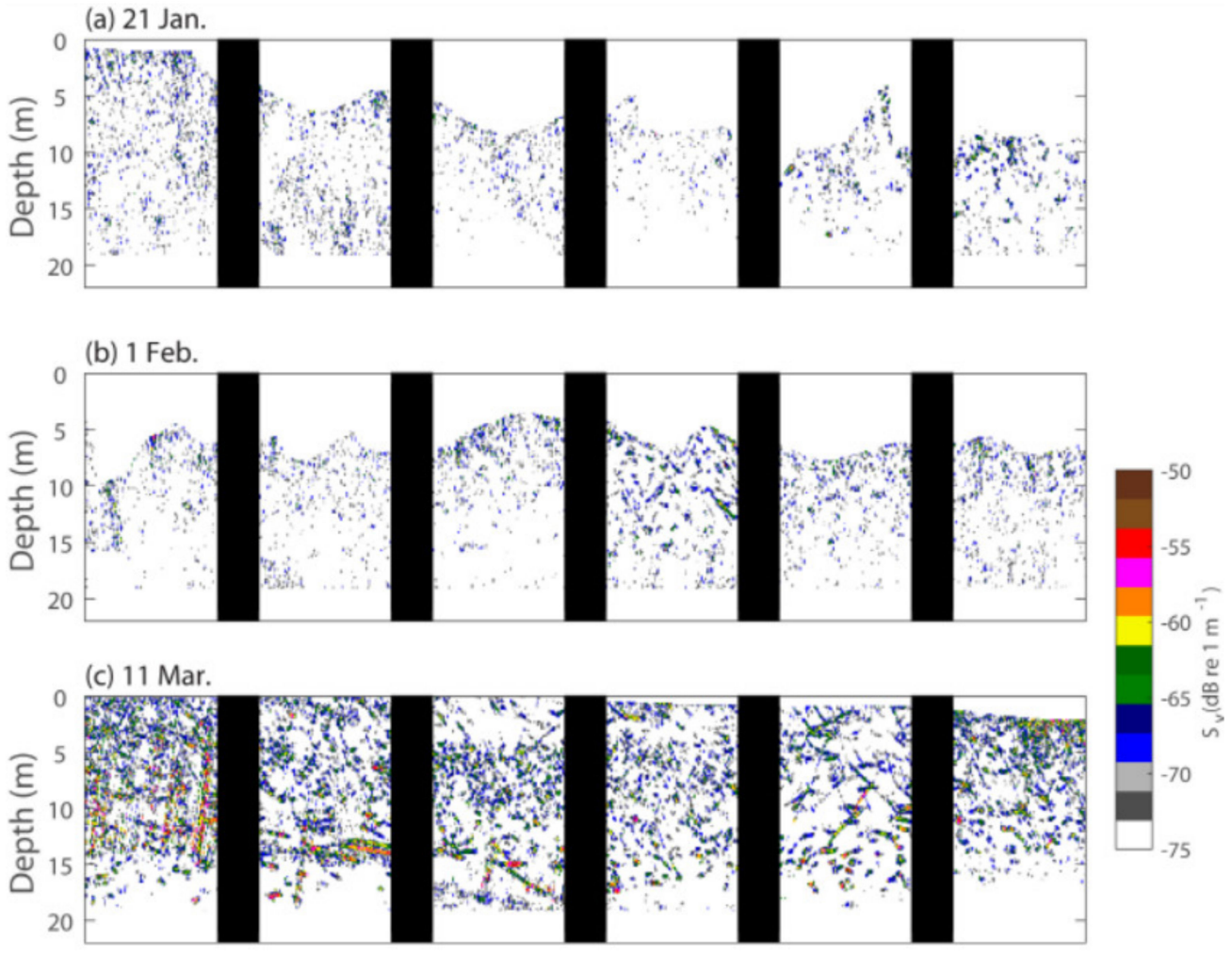

(d) 21 Mar.



Figure 9. Echograms from the mooring highlighting the change in fish signals at the site. The records start at 0000, 0100, 0200, 0300, 0400, and $0500 \mathrm{~h}$ local time on (a) 21 January , (b) 1 February, (c) 11 March and (d) 21 March 2018, indicated and last 600 s.

The TS of herring at $70 \mathrm{kHz}$ from 22.0 to $37.7 \mathrm{~cm}$ in January was calculated as -39.94 to $-35.26 \mathrm{~dB}$, and TS of adults collected from 23.6 to $29.1 \mathrm{~cm}$ in April was -39.10 to 
$-38.30 \mathrm{~dB}$ [23]. The TS range of the smaller herring from 7.9 to $16.2 \mathrm{~cm}$ was -48.84 to $-42.60 \mathrm{~dB}$. These echo levels were higher than the SV echoes detected in the mooring system. The net used during the survey mainly collected adults and large herring larvae. Thus, the detected acoustic echoes were judged to be of smaller herring larvae than the caught herring larvae.

We obtained acoustic echoes with various acoustic frequencies to interpret the spatiotemporal distribution of Pacific herring in the bay [27]. The ship-type acoustic survey was conducted using 38 and $120 \mathrm{kHz}$, and the acoustic frequency of the mooring system was $70 \mathrm{kHz}$. All three frequencies are mainly used for acoustic surveys, and 38 and $120 \mathrm{kHz}$ acoustic data are used to identify fish from zooplankton using the characteristic frequency $[13,28]$. Acoustic survey using $70 \mathrm{kHz}$ frequency is mainly used for the detection of medium-size fish among general zooplankton such as Antarctic krill [29]. In data analysis, the MVBS technique was used to remove zooplankton echoes within the $38 \mathrm{kHz}$ echoes [12], while fish echoes were removed from within the $120 \mathrm{kHz}$ echoes [21]. The $70 \mathrm{kHz}$ echoes obtained by the mooring system differed significantly from those of larval Pacific herring having swimbladders [23] and large copepods mainly distributed in Jinhae Bay [25], with the largest difference being more than $27 \mathrm{~dB}$ per single individual. Therefore, the purpose of acoustic data obtained by the ship-type acoustic survey is to detect adult herring moving to the spawning ground in Jinhae Bay and to identify the spatiotemporal distribution. The mooring-type survey focused on detecting the timing of herring larvae that hatched in the inner bay and moved into the open sea for migration. Although there are limitations in accurate length distribution and fish species identification by net and trawl survey, when using acoustic techniques, they can be interpreted through comparison with acoustic data, existing research results, and catch data.

Although the average monthly surface water temperature increased with the transition of seasons, the water temperatures in March, April, and May 2018 were recorded to be $0.74-1.52{ }^{\circ} \mathrm{C}$ lower than that in the same period in 2016 and 2017 (Figure 8). This may have affected the spawning, growth, and migration time of larvae, including that of the Pacific herring. The results of the temporal and spatial distribution of organisms and fishing using the acoustic method were similar to those of the Pacific herring. Although previous studies found that larvae and immature fish would have already moved to the open sea by April, the results of the acoustic survey and collection data analysis indicated that the fish remained in Jinhae Bay. To investigate the timing of the complete movement of adult and immature Pacific herring to the open sea, it is necessary to carry out follow-up research and therefore, to keep the moored echosounder on the seabed for a longer duration.

The spatiotemporal acoustic signals detected by the moored and ship-based echosounders during winter and spring in Jinhae Bay might not have been only from the Pacific herring but also from other cold-water fishes, including the Pacific cod. In addition, even an analysis using the difference in mean volume backscattering strength with multiple frequencies can produce some errors due to other fish species in the water layer. For this reason, this study installed an underwater camera to supplement the moored echosounder data by distinguishing and identifying fish species accurately and comparing and analyzing the results. However, it was challenging to identify the different species accurately due to issues in the internal battery of the camera in the underwater mount. Thus, follow-up research is required to repeat the same survey and analysis of the collected data using a camera, in order to identify the fish species accurately and analyze the acoustic data.

\section{Conclusions}

This study investigated the spatiotemporal distribution of Pacific herring in Jinhae Bay through an acoustic survey. To this end, a moored echosounder was installed from 21 January to 31 March 2018, where Pacific herring adults and larvae are expected to pass through during their migration to spawning grounds, and two acoustic surveys were conducted in January and April using a ship-based echosounder. In addition, to identify fish species in Jinhae Bay, surveys were performed using a stationary net twice, 
in January and April 2018, and the results were compared with the data from the moored and ship-based echosounders. From the analysis of the ship-based acoustic survey, strong signals considered to be originating from fish were detected on an irregular basis outside Jinhae Bay in January (winter), while a low level of acoustic backscatter intensity, which is considered to originate from fish larvae and zooplankton, was detected continuously inside the bay in April (spring). The data from the moored echosounder installed in the relatively outer part of the bay showed few acoustic signals from January to early March, 2018; however, the acoustic scattering signals continued to increase from mid-March. As a result of the survey with stationary net-fishing, only adult Pacific herring were caught in January 2018, while the adult and immature Pacific herring were found in April 2018. This hydroacoustic survey using a moored echosounder provided a new approach to research spawning grounds, for which accurate survey timing is important, by taking advantage of obtaining continuous data. In addition, this study is expected to serve as the basic data for more effective management of Pacific herring, which tend to return to their spawning grounds.

Author Contributions: H.L., K.L., and W.O. performed the mooring type and ship-based acoustic survey and analyzed the data; J.H.C., S.Y.M., and Y.J.I. discussed the comparison of acoustic results and herring ecology. K.H. and D.N.K. wrote the manuscript and offered useful suggestions. All authors have read and agreed to the published version of the manuscript.

Funding: This research was funded by National Institute of Fisheries Science (R2021027), Korea.

Informed Consent Statement: Not applicable.

Data Availability Statement: Not applicable.

Conflicts of Interest: The authors declare no conflict of interest.

\section{References}

1. NFRDI. Ecology and Fishing Ground of Fisheries Resources in Korea Waters; National Fisheries Research and Development Institute: Busan, Korea, 2010; p. 90.

2. Gong, Y.; Suh, Y.S.; Suh, K.T.; Han, I.S. Fluctuations in Ocean Climate and Fish Populations; National Fisheries Research and Development Institute: Busan, Korea, 2009; p. 263.

3. Statistic Database for Fishery Production Survey. Available online: http:/ / kosis.kr/ (accessed on 14 January 2021).

4. Jung, S. Asynchronous responses of fish assemblages to climate-driven ocean regime shifts between the upper and deep layer in the Ulleung basin of the East Sea from 1986 to 2010. Ocean Sci. J. 2014, 49, 1-10. [CrossRef]

5. Huh, S.H.; Han, M.I.; Hwang, S.J.; Park, J.M.; Baeck, K.W. Seasonal variation in species composition and abundance of larval fish assemblages in the southwestern Jinhae Bay, Korea. Korean J. Ichthyol. 2011, 23, 37-45.

6. Choi, H.C. Species Composition of the Ichthyoplankton and Feeding Ecology of Early Stage in the Nakdong River Estuary, Korea. Ph.D. Thesis, Pukyong National University, Busan, Korea, 2014.

7. Yoon, S.C.; Yang, J.H.; Park, J.H.; Choi, Y.M.; Park, J.H.; Lee, N.W. Feeding Habits of the Pacific Cod Gadus macrocephalus in the Coastal Waters off Jumunjin, Gangwondo of Korea. Korean J. Fish. Aquat. Sci. 2012, 45, 379-386. [CrossRef]

8. Moon, S.Y.; Choi, J.H.; Lee, H.W.; Kim, J.N.; Heo, J.S.; Gwak, W.S.; Lee, Y.D. Distribution and Characteristics of Pacific Herring Clupea pallasii Spawning Beds in Jinhae Bay, Korea. Korean J. Fish. Aquat. Sci. 2019, 52, 534-538. [CrossRef]

9. Kim, H.J.; Jeong, J.M.; Park, J.H.; Baeck, G.W. Feeding habits of larval Clupea pallasii in the Eastern Jinhae Bay, Korea. J. Korean Soc. Fish. Technol. 2017, 53, 107-113. [CrossRef]

10. Lee, Y.D.; Lee, G.M.; Park, J.Y.; Gwak, W.S. Estimation of Spawning Season of Clupea pallasii in the Jinhae Bay and Coastal Waters of Tongyeong in Gyeongnam Using Scuba Observation. Korean J. Ichthyol. 2020, 32, 14-20. [CrossRef]

11. Kang, D.H.; Im, Y.J.; Lee, C.W.; Yoo, J.T.; Myoung, J.G. Hydroacoustic Survey of Spatio-Temporal Distribution of Demersal Fish Aggregations Near the West Coast of Jeju Island, Korea. Ocean. Polar Res. 2008, 30, 181-191. [CrossRef]

12. Lee, H.B.; Kang, D.H.; Im, Y.J.; Lee, K.H. Distribution and Abundance of Japanese Anchovy Engraulis japonicus and Other Fishes in Asan Bay, Korea, estimated Hydroacoustic Survey. Korean J. Fish. Aquat. Sci. 2014, 47, 671-681. [CrossRef]

13. Kang, M.; Seo, Y.I.; Oh, T.Y.; Lee, K.; Jang, C.S. Estimating the biomass of anchovy species off the coast of Tongyeong and Yeosu in South Korea in the spring and winter of 2013 and 2014. J. Korean Soc. Fish. Technol. 2015, 51, 86-93. [CrossRef]

14. Lee, H.; Lee, K.; La, H.S.; Yang, Y.; Kim, P. Acoustic monitoring using bamboo set net in the Southern Sea of Korea. Ocean Sci. J. 2017, 52, 67-74. [CrossRef]

15. Kitamura, M.; Amakasu, K.; Kikuchi, T.; Nishino, S. Seasonal dynamics of zooplankton in the southern Chukchi Sea revealed from acoustic backscattering strength. Cont. Shelf Res. 2017, 133, 47-58. [CrossRef] 
16. La, H.S.; Ha, H.K.; Kang, C.Y.; Wåhlin, A.; Shin, H.C. Acoustic backscatter observations with implications for seasonal and vertical migrations of zooplankton and nekton in the Amundsen shelf (Antarctica). Estuar. Coast. Shelf Sci. 2015, 152, 124-133. [CrossRef]

17. Lawson, G.L.; A Rose, G. Small-scale spatial and temporal patterns in spawning of Atlantic cod (Gadus morhua) in coastal Newfoundland waters. Can. J. Fish. Aquat. Sci. 2000, 57, 1011-1024. [CrossRef]

18. De Robertis, A.; Levine, R.; Wilson, C.D. Can a bottom-moored echo sounder array provide a survey-comparable index of abundance? Can. J. Fish. Aquat. Sci. 2018, 75, 629-640. [CrossRef]

19. Myriax. Echoview; Version 8.0; Myriax Software Pty. Ltd.: Hobart, Australia, 2017.

20. MacLennan, D.N.; Simmonds, E.J. Fisheries Acoustics: Theory and Practice, 2nd ed.; John Wiley \& Sons: Hoboken, NJ, USA, 2008; pp. 59-60.

21. Watkins, J.L. Verification of the acoustic techniques used to identify Antarctic krill. ICES J. Mar. Sci. 2002, 59, 1326-1336. [CrossRef]

22. Moon, S.Y.; Lee, J.H.; Choi, J.H.; Ji, H.S.; Yoo, J.T.; Kim, J.N.; Im, Y.J. Seasonal Variation of Larval Fish Community in Jinhae Bay, Korea. Environ. Biol. Res. 2018, 36, 140-149. [CrossRef]

23. Park, M.; Yoon, E.; Hwang, K.; Lee, D.; Oh, W.; Lee, K. Variation of target strength by swimming orientation and size for Pacific herring (Clupea pallasii) at the frequency of 70-kHz. J. Korean Soc. Fish. Technol. 2017, 53, 396-403. [CrossRef]

24. Korneliussen, R.J.; Heggelund, Y.; Macaulay, G.J.; Patel, D.; Johnsen, E.; Eliassen, I.K. Acoustic identification of marine species using a feature library. Methods Oceanogr. 2016, 17, 187-205. [CrossRef]

25. Soh, H.Y.; Choi, S.D. Species Composition and Occurrence Patterns of Zooplankton. Korean J. Environ. Biol. 2004, $22,43-56$.

26. Sakinan, S.; Lawson, G.L.; Wiebe, P.H.; Chu, D.; Copley, N.J. Accounting for seasonal and composition-related variability in acoustic material properties in estimating copepod and krill target strength. Limnol. Oceanogr. Methods 2019, 17, 607-625. [CrossRef]

27. Holliday, D.V.; Pieper, R.E.; Kleppel, G.S. Determination of zooplankton size and distribution with multifrequency acoustic technology. ICES J. Mar. Sci. 1989, 46, 52-61. [CrossRef]

28. McKelvey, D.R.; Wilson, C.D. Discriminant classification of fish and zooplankton backscattering at 38 and $120 \mathrm{kHz}$. Trans. Am. Fish. Soc. 2006, 135, 488-499. [CrossRef]

29. Amakasu, K.; Furesawa, M. The target strength of Antarctic krill (Euphausia superba) measured by split-beam method in a small tank at $70 \mathrm{kHz}$. ICES. J. Mar. Sci. 2006, 63, 36-45. [CrossRef] 